\title{
STRATEGI PROMOSI PARIWISATA \\ DALAM PERSPEKTIF EKONOMI ISLAM
}

\author{
Habiburahman \\ Fakultas Ekonomi dan Bisnis Islam UIN Raden Intan Lampung \\ Email: habib.iain.@yahoo.com
}

\begin{abstract}
Abstrak: Kawasanwisata yang memiliki cukup banyak objek dan daya tarik akan memiliki potensi untuk dikembangkan. Dengan dimanfaatkannya potensi dan peluang pariwisata menjadi suatu industri, diharapkan mampu meningkatkan pendapatan masyarakat maupun daerah.Sampel penelitian dalam analisis ini yaitu di pantai batu lapisKalianda Lampung Selatan. Permasalahan yang dikaji dalam penulisan ini adalah bagaimana implementasi strategi promosi yang perlu dilakukan dalam meningkatkan pengelolaan wisata. Sehingga penelitian ini bertujuan untuk mengetahui implementasi strategi promosi pariwisata dan faktor pendukungnya. Penelitian dengan (field research) yang bersifat kualitatif, pengumpulan data menggunakan metode observasi, wawancara, dan dokumentasi. Sedangkan analisisnya menggunakan analisa kualitatif (non statistik) yang bersifat deskriptif kualitatif, dengan menggunakan cara berfikir induktif.Berdasarkan hasil penelitian menunjukan strategi yang dilakukan pengelola pantai batu lapis di Kalianda Lampung Selatan sudah sesuai denganstrategi promosi pariwisata dalam perspektif ekonomi Islam yaitukejujuran, keikhlasan dan kepercayaan, dan dilihat dari etika promosi dalam Islam jugatidak mengobral sumpah, tidak mengingkari janji, jujur, menghindari adanya penipuan, dan rela dengan laba yang sedikit tetapi berkah.
\end{abstract}

Kata Kunci: Strategi Promosi Pariwisata

\begin{abstract}
Tourist areas that have enough objects and attractions will have the potential to be developed. With the exploitation of tourism potential and opportunities into an industry, is expected to increase the income of the community and the region. The research sample this analysis is coast at Kalianda of South Lampung. The problems studied in this paper is how the implementation of promotional strategies that need to be done in improving tourism management. This study aims to determine the implementation of tourism promotion strategies and supporting factors. Research with (field research) is qualitative, data collection using observation methods, interviews, and documentation. While the analysis using qualitative analysis (non statistics) which is descriptive qualitative, by using inductive thinking. Based on the results of research in coast at Kalianda of South Lampung, accordance with tourism promotion strategy in the perspective of Islamic economics that is honesty, sincerity and trust, and seen from the ethics of promotion in Islam also not sell out oath, not to promise, honest, Avoid fraud, and be willing to profit a little but a blessing.
\end{abstract}

Keywords: Tourism Promotion Strategy

\section{PENDAHULUAN}

Strategi merupakan cara terbaik yang dijalankan untuk mencapai tujuan tertentu. Selain itu pula strategi adalah suatu cara atau langkah-langkah yang harus ditempuh oleh 
perusahaan dalam mencapai tujuannya dalam menentukan persaingan dengan para kompetitornya (Fandy:3). Dari strategi perlu adanya promosi atau yang juga dikenal dengan komunikasi pemasaran (marketing communications) adalah berbagai cara untuk menginformasikan, membujuk dan mengingatkan konsumen - secara langsung maupun tidak langsung - tentang suatu produk atau brand yang dijual (Sandra : 234). Pariwisata adalah kegiatan dinamis yang melibatkan banyak manusia serta menghidupkan berbagai bidang usaha. Di era globalisasi saat ini, sektor pariwisata akan menjadi pendorong utama perekonomian dunia dan menjadi industri yang mengglobal. Pariwisata akan memberikan banyak pemasukan bagi daerah yang sadar akan potensinya terhadap sektor pariwisata, peningkatan jumlah pengunjung suatu wisata dapat diartikan sebagai kegiatan pengorganisasian secara menyeluruh yang mencakup pengembangan atau pembangunan pariwisata sehingga fasilitas-fasilitas tersebut dapat memenuhi tugas-tugas sebagaimana mestinya. Ekonomi Islam adalah ilmu yang mempelajari usaha manusia untuk mengalokasikan dan mengelolah sumberdaya untuk mencapai falah berdasarkan pada prinsip-prinsip dan nilai-nilai Al-Qur'an dan Sunnah.

Sejak zaman Rasulullah SAW, Islam telah mengajarkan tentang etika dalam bisnis termasuk cara pemasaran yang sesuai dengan ajaran Islam. Islam juga mengatur semua tentang kehidupan tanpa terkecuali, termasuk dalam lingkup bisnis. Dalam literatur lain, disebut juga bahwa bahwa bisnis dalam literatur Islam disebut syirkah. Pemasaran syariah merupakan disiplin bisnis strategi yang mengarahkan proses penciptaan,penawaran, dan perubahan value dan suatu inisiator dan prinsip-prinsip muamalah dalam islam.(Aziz: 15).

Dalam islam promosi sangat dianjurkan tetapi harus berpegang pada kebenaran (kenyataan),orang yang beriman perkataannya harus sesuai dengan perbuatannya (jujur) karena sangat berdosa besar bagi orang-orang yang tidak mampu menyesuaikan perkataannya dengan perbuatan, kejujuran merupakan pondasi utama atas tegaknya nilainilai kebenaran karena jujur itu identik dengan kebenaran. Berdasarkan penjelasan diatas, dapat digambarkan kompleksnya masalah promosi dalam suatu perusahaan atau lembaga, strategi yang tepat pun merupakan hal yang penting dalam menyampaikan pesan melalui media promosi. Sudah pasti pengelola ingin selalu meningkatkan jumlah pengunjung, dan dapat dilihat kegiatan promosi mempunyai peran dalam upaya meningkatkan tujuan pengelola yaitu meningkatkan minat pengunjung. Dari hal tersebut tampak bahwa Islam memberikan solusi dengan menunjukkan jalan yang aman untuk ditempuh sebagai pebisnis tanpa melanggar etika-etika kemanusiaan.

Pedoman Islam tentang masalah kerja tidak membolehkan umatnya untuk bekerja mencari uang dengan sesuka hatinya dan jalan yang tidak baik, seperti penipuan, kecurangan, dan perbuatan bathil lainnya. Tetapi Islam memberikan kepada mereka suatu garis pemisah antara yang boleh dan tidak boleh dalam mencari pembekalan hidup, dengan menitikberatkan juga kepada masalah kemaslahatan umum, seperti suka sama suka, sehingga tidak ada pihak yang merasa dirugikan dan dizalimi. Semua jalan yang saling mendatangkan manfaat antara individu-individu yang saling rela-merelakan, dan adil adalah dibenarkan (Viethzal:26).

Sampel dalam penlitian ini yaitu pantai Batu Lapis ini berada di pesisir pantai Batu Balak, Kec.Rajabasa, lampung selatan, kira-kira $25 \mathrm{KM}$ dari pusat kota Kalianda.Sehingga hasil dari penelitian nanti dapat mendeskripsikan dan menganalisis bagaimana stategi promosi yang ditetapkan oleh pengelola pantai batu lapis perspektif ekonomi Islam.Penelitian ini menggunakan penelitian lapangan (field research) yaitu penelitian langsung di lapangan, penelitian ini meneliti kondisi obyektif di lapangan serta di 
masyarakat yang berlokasi di desa Kunjir, Kalianda Lampung Selatan. Dan penelitian ini akanmenggambarkan atau memaparkan peristiwa, tidak mencari hubungan antaravariabel. Dalam penelitian ini penulis menggambarkan atau menjelaskan data yang terkait dengan pembahasan, dimana tekhnik ini menggambarkan tentang strategi promosi pariwisata guna meningkatkan jumlah pengunjung dalam perspektif ekonomi Islam. Sehingga dari latar belakang diatas perlu dianalisis bagaimana strategi promosi yang dilakukan oleh pengelola pantai batu lapis dalam meningkatkan jumlah pengunjung dalam perspektif ekonomi Islam.

Ekonomi Islam Tentang Promosi. Ekonomi Islam menerapkan promosi yang dilakukan untuk menawarkan, menginformasikan, menjual produk atau jasa di pasar. Karena dengan promosi masyarakat akan mengetahui keberadaan produk atau jasa.

Prinsip yang digunakan oleh Nabi Muhammad SAW, adalah personal selling, iklan, promosi penjualan dan humas. Namun cara-cara yang ditetapkan oleh Nabi Muhammad SAW berbeda dengan promosi yang dilakukan pada saat ini. Cara yang dilakukan Nabi Muhammad SAW tidak lepas dari nilai-nilai moralitas.Promosi pada era nabi belum berkembang seperti sekarang ini, dimana seluruh produsen telah menggunakan alat yang serba modern, media internet, televisi, radio dan lain-lain. Dalam istilah manajemen sifat dari nabi dapat diterjemahkan sebagai supel, cerdas, deskripsi tugas, delegasi wewenang, kerja tim, cepat tanggap, kordinasi, kendali dan supervise. Bauran promosi merupakan kombinasi dari alat-alat promosi, yaitu periklanan, penjualan tatap muka (personal selling), promosi penjualan dan publisitas yang dirancang untuk menjual barang dan jasa. Untuk menjual barang dan jasa secara langsung kita telah melakukan kegiatan bisnis.

Dalam konsep Al-Qur'an tentang bisnis juga sangat komprehensif, parameter yang dipakai tidak menyangkut dunia saja, namun juga menyangkut urusan akhirat. Al-Qur'an memandang kehidupan manusia sebagai sebuah proses yang berkelanjutan. Manusia harus bekerja bukan hanya untuk meraih sukses di dunia namun juga kesuksesan di akhirat (Ahmad: 35).

Menurut prinsip syariah, kegiatan pemasaran harus dilandasi semangat beribadah kepada Tuhan Sang Maha Pencipta, berusaha semaksimal mungkin untuk kesejahteraan bersama, bukan untuk kepentingan golongan apalagi kepentingan sendiri. Strategi promosi dalam ekonomi Islam yaitu:

\section{a. Ekonomi Islam Tentang Media Iklan}

Prinsip ekonomi Islam yang dipakai yaitu kebenaran dan kejujuran. Dalam ekonomi Islam mempromosikan suatu produk melalui iklan, kebenaran dan kejujuran adalah dasar nilai ekonomi Islam. Islam sangat melarang kebohongan dalam berbagai bentuk. Maka dari itu setiap pengelola harus berlaku jujur, benar dan lurus dalam melakukan promosi sesuai dengan iklan yang ditampilkan. Tidak boleh berlaku curang, berkata bohong, bahkan mengumbar sumpah atau iklan palsu.

Suatu informasi produk walaupun dengan secara bebas memilih kreasi penyampaianya, tetapi dibatasi oleh pertanggungjawaban secara horizontal dan vertikal sekaligus. Suatu kebebasan yang tak terkendali yang membuat suatu pasti tidak akan membawa dampak positif walaupun dalam jangka pendek mungkinmenguntungkan. Demikian pula nilai kebenaran harus dijunjung tinggi untuk mempertahankan suatu tujuan luhur dari bisnis. Kebebasan dalam kreasi penyampaiannya harus diimbangi dengan pertanggungjawaban manusia. Jadi iklan Islami adalah bentuk komunikasi tidak langsung yang didasari pada 
informasi mengenai suatu produk yang bertujuan untuk mempengaruhi konsumen dan dalam penyajianya berlandaskan pada etika periklanan Islami.

Pengiklan juga harus menghindariiklan yang menipu dan 23berlebihan yang dianggap sebagai bentuk kebohongan. Kebenaran fakta dalam informasi yang disampaikan kepada publik.

\section{b. Ekonomi Islam Tentang Promosi Penjualan}

Prinsip ekonomi Islam yang dipakai dalam promosi penjualan yaitu kepercayaan dan suka sama suka. Pengelola pantai batu lapis tidak memaksa para wisatawan untuk memakai jasanya, transaksi terjadi atas dasar suka sama suka dan kepercayaan. Orang yang terjun dalam bidang usaha jual beli harus mengetahui hukum jual beli agar dalam jual beli tersebut tidak ada yang dirugikan, baik dari pihak penjual maupun pihak pembeli. Jual beli hukumnya mubah. Artinya, hal tersebut diperbolehkan sepanjang suka sama suka. Apabila seseorang melakukan jual beli dan tawar menawar dan tidak ada kesesuaian harga antara penjual dan pembeli, si pembeli boleh memilih akan meneruskan jual beli tersebut atau tidak. Apabila akad (kesepakatan) jual beli telah dilaksanakan dan terjadi pembayaran, kemudian salah satu dari mereka atau keduanya telah meninggalkan tempat akad, keduanya tidak boleh membatalkan jual beli yang telah disepakatinya.

\section{c. Ekonomi Islam Tentang Penjualan Pribadi (personal selling)}

Prinsip ekonomi Islam yang dipakai dalam penjualan pribadi yaitu keikhlasan. Islam menetapkan keikhlasan sangat penting dalam setiap langkah kehidupan manusia. Berdasarkan hal itu, keikhlasan pelaku bisnis diharapkan tidak berlaku curang ataupun melanggar kepentingan orang lain dengan sengaja.Pada saat presentasi tenaga penjual menguraikan fitur-fitur produk bagi pelanggan. Menggunakan pendekatan kepuasan kebutuhan. Biasanya mereka menjelaskan fitur-fitur penting dari produknya, menonjolkan kelebihan-kelebihannya dan menyebutkan contoh-contoh kepuasan konsumen. Oleh karena itu pada saat presentasi, tenaga penjual harus dipersiapkan dengan baik, dilatih kembali apa yang mereka katakan, menggunakan kontak mata langsung, bertanya dengan pertanyaaan terbuka dan bersikap tenang. Meskipun demikian, dalam mempresentasikan suatu produk diharapkan untuk berbicara jujur dan bisa memenuhi janji-janjinya.

Islam memerintahkan umatnyauntuk jujur termasuk dalam berbisnis. Dengan sikap kejujuran, pembeli akan bertambah karena Allah SWT akan memberikan kelebihan pada orang jujur itu. Sedangkan pembeli tentu juga akan memberikan informasi tentang kejujuran dan kebaikan pedagang itu kepada yang lain, sehingga pembelinya bertambah.

Jika meneladani Rasulullah SAW, saat melakukan kegiatan promosi, maka beliau sangat mengedepankan adab dan etika yang luar biasa. Etika dan adab inilah yang dapat disebut sebagai strategi. Menurut Madjid Fakhri etika yang harus dilakukan dalam berpromosi sesuai dengan anjuran islam adalah:

1) Jangan pernah mengobral sumpah, dalam beriklan atau berpromosi janganlah mudah mengucapkan janji sekiranya janji tersebut tidak bisa ditepati. Bersumpah secara berlebihan dilarang dalam etika promosi Islam, mengobral sumpah tanpa sesuai dengan yang sesunggungnya dapat merusak nilai-nilai islami. Allah SWT. Dan Rasulullah memberi aturan dan larangan dalam hal ini. Dari Abu Qotadah Al-Anshori, Nabi shalallahu 'alaihi wa sallam bersabda: " bahwasannya ia mendengar Rasullullah SAW bersabda: Hati-hatilah dengan banyak bersumpah dalam menjual dagangan karena ia memang melariskan dagangan, namun malah menghapuskan (keberkahan)"(HR.Tirmizi). Bersumpah secara berlebihan dilarang dalam etika 
promosi Islam, mengobral sumpah tanpa sesuai dengan yang sesungguhnya dapat merusak nilai-nilai Islam.

2) Jujur, Islam sangat melarang memalsu dan menipu karena dapat menyebabkan kerugian dan kedzaliman serta dapat menimbulkan permusuhan dan percecokan. Hadist yang Agung ini menunjukkan besarnya keutamaan seseorang pedagang yang memiliki sifat-sifat ini, karena ia akan dimuliakan dengan keutamaan besar dan kedudukan yang tinggi disisi Allah SWT, dengan dikumpulkan bersama para nabi, orang-orang shiddiq dan orang-orang yang mati syahid pada hari kiamat. Alqur'an dengan tegas melarang ketidakjujuran, menjaga agar selalu memenuhi akad dan janji serta kesepakatan-kesepakatan diantara kedua belah pihak (pembeli dan penjual).

3) Menghindari berpromosi palsu yang bertujuan menarik perhatian pembeli dan mendorongnya untuk membeli. Berbagai iklan dimedia televisi atau dipajang dimedia cetak, media indoor atau outdoor, atau lewat radio sering kali memberikan keterangan palsu. Model promosi tersebut melanggar akhlaqul karimah. Islam sebagai agama yang menyeluruh, mengatur tata cara hidup menusia, setiap bagian tidak dapat dipisahkan dengan bagian yang lain. Demikian pula pada proses marketing, jual beli harus berdasarkan etika Islam. Demikian pula pada proses marketing, jual beli harus berdasarkan etika Islam.

Rela dengan laba yang sedikit karena itu akan mengundang kepada kecintaan manusia dan menarik banyak pelanggan serta mendapat berkah dalam rezeki. Jika penguasa ingin mendapatkan rezeki yang berkah dengan berprofesi sebagai pedagang, tentu ingin dinaikan derajatnya setara dengan para nabi, maka ia harus mengikuti syariah Islam secara menyeluruh, termasuk dalam jual beli (Ali:25-26). Bahwa konsep jual beli dalam islam adalah suka sama suka atau kerelaan, dimana kedua belah pihak sama-sama dengan terjadinya transaksi itu.

\section{HASIL DAN PEMBAHASAN}

Strategi Promosi Pariwisata Guna Meningkatkan Jumlah Pengunjung Dalam Perspektif Ekonomi Islam. Praktek promosi pariwisata dengansempel penelitian di pantai batu lapis di Kalianda Lampung dalam tinjauan ekonomi Islam untuk melihat sudah relevan atau tidak etika promosi pada objek wisata pantai batu lapis di Kalianda, bagian dari etika bisnis menunjuk kepada studi tentang aspek-aspek moral dari kegiatan ekonomi dan bisnis. Moral adalah sistem nilai tentang apa yang dianggap baik dan dianggap buruk. Adapun etika yang dilakukan pengelola pantai batu lapis di kalianda dalam berpromosi sesuai dengan Islam, antara lain:

a. Jangan mudah mengobral sumpah dalam berpromosi atau beriklan, janganlah mudah mengucapkan janji sekiranya janji tersebut tidak bisa ditepati. Bersumpah secara berlebihan dilarang dalam etika promosi Islam, mengobral sumpah tanpa sesuai dengan yang sesungguhnya dapat merusak nilai Islami. Allah SWT dan Rasulnya memberikan larangan. Dari Abu Qotadah Al-Anshori, Nabi shalallahu 'alaihi wa sallam bersabda: Bahwasannya ia mendengar Rasullullah SAW bersabda "Hatihatilah dengan banyak bersumpah dalam menjual dagangan karena ia memang melariskan dagangan, namun malah menghapuskan (keberkahan)..."(HR.Tirmizi). Dijelaskan pula oleh Yusanto dan Widjadjakusuma, bahwa pebisnis muslim akan menghindari iklan porno, bohong, dan promosi yang menghalalkan segala cara. Berdasarkan teori tersebut dan dianalisis dari hasil penelitian dilapangan bahwa 
strategi promosi yang dilakukan oleh pengelola pantai batu lapis sudah sesuai dengan teori yang dijabarkan.

Hasil penelitian dengan sempel penelitian di pantai batu lapis di Kalianda Lampung, Bahwa pengelola pantai tidak pernah mengobral janji-janji atau bahkan mengobral sumpah pada konsumennya, mereka selalu menjelaskan apa adanya yang berkaitan dengan layanan jasa yang ditawarkan.

b. Jujur; Islam melarang berbohong dan menipu karena dapat menyebabkan kerugian dan kedzaliman serta dapat menimbulkan permusuhan. Ketika akan memulai berbisnis, hal pertama yang perlu ditanamkan niat yang baik, merumuskan visi dan misi dan filosofi bisnis yang baik, lalu menjalankan bisnis dengan sikap kejujuran. Dengan demikian, tidak akan mudah tergoda atau terjerumus dengan hal-hal yang bersifat materi, sehingga menghalalkan segala cara untuk memajukan bisnis.

Berdasarkan hasil penelitian dengan sempel penelitian di pantai batu lapis di Kalianda Lampung,pihak pengelola pantai selalu bertindak jujur kepada para wisatawan dalam hal beriklan atau memberikan informasi seputar objek wisata pantai batu lapis. Dan tidak pernah menipu para wisatawan. Karna dengan jujur akan menalankan bisnis dengan tenang, serta mengangkat harkat dan martabat objek wisata, selain itu dengan jujur akan menghasilkan keuntungan di dunia dan akhirat.

c. Menjaga agar selalu memenuhi akad dan janji. Berdasarkan hasil penelitian dengan sempel penelitian di pantai batu lapis di Kalianda Lampung, pewngelola sudah memegang perkataan atau janji dengan uji pada waktu perjalanan menuju objek wisata dengan menggunakan perahu wisata, pihak pengelola berjanji untuk menghantarkan dan menunggu saat nanti para wisatawan ingin kembali pulang dari tempat wisata tersebut.

d. Menghindari promosi palsu yang bertujuan menarik perhatian wisatawan dan mendorongnya untuk berkunjung, berbagai iklan di media elektronik dan cetak, model promosi tersebut banyak yang telah melangar akhlaqul karimah. Sebagaimana teori yang telah dijabarkan bahwa apabila seorang pemasar syari'ah hanya berorientasi pada keuntungan maka ia dapat merugikan para wisatawan dengan memberikan janji palsu. Namun seorang pemasar syari'ah memiliki orientasi maslahah, sehingga tidak hanya mencari keuntungan namun diimbangi dengan keberkahan didalamnya

Demikian pula pada proses marketing, jual beli harus berdasarkan etika Islam. Oleh karena itu dibidang promosi jasa dan etika pemasaran islam pantai batu lapis mengikuti aturan yang sudah dibuat sebelumnya. Menghindari promosi penjualan yang menggunakan penipuan dan manipulasi

e. Rela dengan laba yang sedikit karena itu akan mengundang kepada kecintaan manusia dan banyak pelanggan serta mendapat berkah dalam rezeki, dengan profesi sebagai pedagang jasa, tentu ingin dinaikkan derajatnya setara dengan para nabi, maka ia harus mengikuti syari'ah Islam. Ibnu Hibban dan Ibnu Majah mengeluarkan hadits dari Nabi SAW :

Artinya: "Sesungguhnya jual beli itu atas prinsip saling rela.

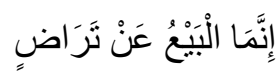

Objek wisata pantai batu lapis di Kalianda tidak pernah berlebihan dalam menetukan laba. Setelah menganalisis teori tentang strategi promosi dalam Islam yang dilakukan oleh pengelola pantai batu lapis di Kalianda. Dapat disimpulkan bahwa didalam Islam dilarang keras melakukan penipuan, kebohongan, dan mengingkari janji. Oleh karena itu dalam pelaksanaan promosi pebisnis muslim harus menghindari tindakan 
kebohongan, janji palsu, serta publikasi produk atau jasa yang menghalalkan segala cara.

Aktifitas bisnis merupakan bagian dari kegiatan ekonomi, sistem ekonomi Islam berangkat dari kesadaran tentang etika, sedangkan ekonomi lain seperti kapitalisme dan sosialisme, cenderung mengabaikan etika sehingga aspek nilai tidak begitu tampak dalam bangunan kedua sistem ekonomi tersebut. Karena didalam situasi dunia bisnis membutuhkan etika, Islam telah menyerukan urgensi etika bagi aktifitas bisnis, Islam merupakan sumber nilai dan etika dalam segala aspek kehidupan dan aspek manusia secara menyeluruh.

Berdasarkan hasil penelitian yang penulis lakukan di objek wisata pantai batu lapis di Kalianda, penulis mendapati bahwa dalam proses promosi yang dilakukan pengelola pantai batu lapis di Kalianda telah sesuai dengan ekonomi Islam. Nilai-nilai yang telah diterapkan oleh pengelola pantai batu lapis di Kalianda antara lain :

f. Ekonomi Islam tentang media iklan

Prinsip ekonomi Islam yang dipakai yaitu kebenaran dan kejujuran. Dalam ekonomi Islam mempromosikan suatu produk melalui iklan, kebenaran dan kejujuran adalah dasar nilai ekonomi Islam. Islam sangat melarang kebohongan dalam berbagai bentuk. Maka dari itu setiap pengelola harus berlaku jujur, benar dan lurus dalam melakukan promosi sesuai dengan iklan yang ditampilkan. Tidak boleh berlaku curang, berkata bohong, bahkan mengumbar sumpah atau iklan palsu.

Suatu informasi produk walaupun dengan secara bebas memilih kreasi penyampaianya, tetapi dibatasi oleh pertanggung jawaban secara horizontal dan vertikal sekaligus. Suatu kebebasan yang tak terkendali yang membuat suatu pasti tidak akan membawa dampak positif walaupun dalam jangka pendek mungkin menguntungkan. Demikian pula nilai kebenaran harus dijunjung tinggi untuk mempertahankan suatu tujuan luhur dari bisnis (Muhammad, Alimin : 274)

Kebebasan dalam kreasi penyampaiannya harus diimbangi dengan pertanggung jawaban manusia.Jadi iklan Islami adalah bentuk komunikasi tidak langsung yang didasari pada informasi mengenai suatu produk yang bertujuan untuk mempengaruhi konsumen dan dalam penyajianya berlandaskan pada etika periklanan Islami. Pengiklan juga harus menghindari iklan yang menipu dan berlebihan yang dianggap sebagai bentuk kebohongan.Seperti halnya objek wisata pantai batu lapis di kalianda yang bertindak jujur dalam mempromosikan jasa melalui media iklan, karena iklan yang ditawarkan sesuai dengan yang ditawarkan.

Ekonomi Islam tentang promosi penjualan. Prinsip ekonomi Islam yang dipakai dalam promosi penjualan yaitu kepercayaan dan suka sama suka. Pengelola pantai batu lapis tidak memaksa para wisatawan untuk memakai jasanya, transaksi terjadi atas dasar suka sama suka dan kepercayaan.Orang yang terjun dalam bidang usaha jual beli harus mengetahui hukum jual beli agar dalam jual beli tersebut tidak ada yang dirugikan, baik dari pihak penjual maupun pihak pembeli. Jual beli hukumnya mubah. Artinya, hal tersebut diperbolehkan sepanjang suka sama suka.

Pihak pengelola tidak pernah memaksa pengunjung untuk menggunakan jasa yang disediakan oleh masyarakat pesisir pantai. Pengunjung berhak menolak atau menerima tawaran yang disediakan oleh pengelola dan masyarakat pesisir pantai. Jadi kegiatan penjualan ini didasarkan atas dasar suka sama suka dan tidak ada keterpaksaan yang dapat merugikan sebelah pihak. 
Ekonomi Islam tentang penjualan pribadi (personal selling). Prinsip ekonomi Islam yang dipakai yaitu keikhlasan. Islam menetapkan keikhlasan sangat penting dalam setiap langkah kehidupan manusia. Berdasarkan hal itu, keikhlasan pelaku bisnis diharapkan tidak berlaku curang ataupun melanggar kepentingan orang lain dengan sengaja. Pada saat presentasi tenaga penjual menguraikan fitur-fitur produk bagi pelanggan. Menggunakan pendekatan kepuasan kebutuhan. Biasanya mereka menjelaskan fitur-fitur penting dari produknya, menonjolkan kelebihan-kelebihannya dan menyebutkan contoh-contoh kepuasan konsumen. Oleh karena itu pada saat presentasi, tenaga penjual harus dipersiapkan dengan baik, dilatih kembali apa yang mereka katakan, menggunakan kontak mata langsung, bertanya dengan pertanyaaan terbuka dan bersikap tenang. Meskipun demikian, dalam mempresentasikan suatu produk diharapkan untuk berbicara jujur dan bisa memenuhi janji-janjinya. Pengelola serta masyarakat pesisir pantai dalam objek wisata pantai batu lapis di Kalianda penuh keikhlasan dalam melayani pengunjung dengan ramah tamah serta lemah lembut.

Berdasarkan pemaparan diatas mengenai strategi promosi dalam perspektif ekonomi Islam dapat disimpulkan bahwa berdasarkan prinsip ekonomi Islam dalam berpromosi dan etika bisnis Islam yang terdiri dari kejujuran, amanah, keadilan, dan istiqomah. Prinsip ekonomi Islam dalam berpromosi dan etika bisnis islam tersebut juga diperlukan kekonsistenan untuk diterapkan agar bisnis yang dijalankan sesuai dengan aturan syari'ah yang berasal dari Allah SWT, sebagaimana yang telah dicontohkan oleh Nabi Muhammad SAW.

\section{PENUTUP}

Pariwisata pantai Batu Lapis di Kalianda dalam melaksanakan strategi promosi sudah sesuai dengan syari'at Islam yaitu dilihat dari yang dilakukan pengelola Pantai Batu Lapis di Kalianda dalam berpromosi sesuai dengan Islam yaitu dengan tidak mengobral sumpah dalam berpromosi atau beriklan, jujur, menjaga agar selalu memenuhi akad dan janji serta kesepakatan-kesepakatan diantara kedua belah pihak, menghindari promosi palsu, rela dengan laba yang sedikit karena itu akan mengundang kepada kecintaan manusia dan banyak pelanggan serta mendapat berkah dalam rezeki.

\section{DAFTAR RUJUKAN}

Ahmad Mustag, (2001) The Furture of Economics: An Islamic Perspektif, Asy Syaamil Press \& Grafika, Jakarta.

Ali hasan, (2010) Marketing dan Bank Syariah, Ghalia Indonesia, Bogor.

Andika, F. (2012) Analisa Strategi Marketing Gumati Cafe Dalam Meningkatkan Konsumen Menurut Perspektif Islam. AL-INFAQ, 3(1).

Aziz Hakim Muhammad, (2007) Sistem Operasional Pemasaran Syari'ah, Renaisan, Jakarta.

Dahlan, M. S. Evaluasi Pelaksanaan Strategi Dinas Pariwisata Dan Ekonomi Kreatif Dalam Pengembangan Wisata Bahari Pada Daerah Tertinggal Di Kabupaten Pesisir Barat.

Danang Sunyono, (2012) Dasar-dasar Manajemen Pemasaran, CAPS, Yogyakarta.

Daryanto, (2001) Manajemen Pemasaran, cet. Ke-1, PT. Sarana Tutorial Nuraini Sejahtera. Bandung. 
Departemen Agama RI, (2000) Al-Qur'an dan Terjemahannya Surah al-Ahzab,CV. Diponegoro, Bandung.

Etta Mamang Sangadji, dan Sopiah, (2010) Metodologi Penelitian,C.V ANDI, Yogyakarta.

Fandy Tjiptono, (2001) Strategi Pemasaran, C.V ANDI, Yogyakarta.

Fatimah, S. (2015) Strategi pengembangan objek daya tarik wisata religi (studi kasus di Makam Mbah Mudzakir Sayung Demak) (Doctoral dissertation, UIN Walisongo).

M. Liga Suryadana, Vanny Octavia, (2015) Pengantar Pemasaran Pariwisata, Alfabeta, Bandung.

M. Mursid, (2014) Manajemen Pemasaran, Cet Ke-7, PT Bumi Aksara. Jakarta.

Meflinda, A., Bustam, N., \& Tanjung, H. (2015) "Mapping dan Strategi Pengembangan Potensi Ekonomi Berbasis Budaya Lokal di Provinsi Riau". Jurnal Aplikasi Manajemen-Journal of Applied Management, 13(4), 620-633.

Moh. Pabundu Tika, (2006) Metodologi Riset Bisnis, Bumi Aksara, Jakarta.

Mudrajad Kuncoro, (2009) Metode Riset Untuk Bisnis Dan Ekonomi,Erlangga, Jakarta.

Muhammad, Alimin, (2004) Etika dan Perlindungan Konsumen dalam Ekonomi Islam, BPFE, Yogyakarta.

Nugraheni, Y. (2009) "Peran Paguyuban Kampung Wisata Batik Kauman Dalam Promosi Batik" (Doctoral Dissertation, Universitas Sebelas Maret).

Nyoman S Pendit, Ilmu Pariwisata, Cetakan 8, Jakarta, 2006.

Purnomo, C. (2009) "Strategi Pemasaran Produk Wisata Minat Khusus Goa Cerme, Imogiri, Bantul (English: Marketing Strategy of Special Interest Tourism Product of Cave Cerme, Imogiri, Bantul)". Jurnal KARISMA, 3(2), 99-112.

Pusat Pengkajian Dan Pengembangan Ekonomi Islam, (2007) Ekonomi Islam, Raja Grafindo Persada, Jakrta.

Rambat Lupiyoadi, (2000) Manajemen Pemasaran Jasa, Salemba Empat, Jakarta, 2000.

Rani, D. P. M. (2014) "Pengembangan Potensi Pariwisata Kabupaten Sumenep, Madura, Jawa Timur (Studi Kasus: Pantai Lombang)". Universitas Airlangga: Jurnal Politik Muda, 3(3), 412-421.

Reniati, S. E., \& Si, M. Strategi Pemasaran Pendukung Sektor Pariwisata Berbasis Usaha Mikro Dan Kecil Di Kota Pangkalpinang.

Rizkana, K. (2014) "Strategi Pengembangan Industri Pariwisata Dan Dampaknya Terhadap Kehidupan Masyarakat Di Kabupaten Karimun Menurut Perspektif Ekonomi Islam" (Doctoral Dissertation, Universitas Islam Negeri Sultan Syarif Kasim Riau).

Sofyan Harahab, (2011) Etika Bisnis dalam Perspektif Islam, Salemba Empat, Jakarta.

Sugiono, (2012) Metode Penelitian Kuantitatif Kualitatif dan R\&D, ALFABETA, Bandung.

Sugiyono, (2006) Statistika Untuk Penelitian, Alfabeta, Bandung.

Viethzal Rivai, Amiur Nurddin, Faisar Ananda Arfa, (2012) Islamic Business and Economic Ethics, Bumi Aksara, Jakarta.

Wahab Salah, (2001) Pemasaran Pariwisata, PT Pradnya Paramita,Jakarta.

Widodo, S. (2012) "Potensi Taman Pancing Menurut Perspektif Ekonomi Islam (Studi Kasus Sistem Sewa (Ijarah) Pada Taman Pancing Alam Mayang Kelurahan Tangkerang Timur Pekanbaru)", Doctoral dissertation, Universitas Islam Negeri Sultan Syarif Kasim Riau). 
www.IslamicEconomicsStudyClub/Pariwisata-Dalam-Kaca-Mata-Besar-EkonomiIslam.html.Diakses pada 20 mei 2016 